\title{
Electrophysiological Investigation of the Auditory System in Friedreich's Ataxia
}

\author{
M.J. TAYLOR, J.B. McMENAMIN, E. ANDERMANN, G.V. WATTERS
}

\begin{abstract}
Auditory brainstem responses (ABRS) and cortical auditory evoked responses (AERs) were studied in a series of 16 Friedreich's ataxia patients who varied in age, degree of clinical involvement and duration of the disorder. The ABRs were markedly abnormal in all but the youngest patient, and the abnormalities reflected the severity and duration of the disease. The latencies of the AERs were significantly longer in the Friedreich's ataxia patients compared to normal controls, suggesting cortical as well as peripheral involvement of the auditory system. These data are discussed in terms of the neuropathology of the disorder and the similarities with the other sensory systems in Friedreich's ataxia patients.
\end{abstract}

RÉSUMÉ: Nous avons étudié, chez 16 patients avec ataxie de Friedreich (d'âge, d'atteinte clinique et de durée variables) la réponse évoquée auditive du tronc cérébral $(A B R)$ et les réponses évoquées auditives du cortex (AER). Les $A B R$ étaient nettement anormales chez tous sauf chez le plus jeune patient et ces anomalies reflétaient la sévérité et la durée de la maladie. Les latences $A E R$ étaient significativement plus longues chez les patients que chez les témoins normaux. Ceci suggère qu'il y a une atteinte corticale en plus de l'atteinte périphérique chez ces patients.

From the Division of Neurology, Montreal Children's Hospital; the Department of Pediatrics, University of Toronto; the Division of Neurology, the Hospital for Sick Children, Toronto and the Department of Neurogenetics, Montreal Neurological Institute.

Reprint Request for the complete supplement on Friedreich's ataxia (Phase Three, Part Two) to: Prof. Andre Barbeau, Clinical Research Institute of Montreal, 110 Pine Avenue West, Montreal, Quebec, Canada H2W IR 7 .

\section{INTRODUCTION}

Friedreich's ataxia is a hereditary spino-cerebellar degeneration. Only recently have rigid diagnostic criteria for the disorder been defined by the Quebec cooperative study (Geoffroy et al., 1976). Friedreich's ataxia is a progressive disease with onset usually prior to puberty, characterized by degeneration of the dorsal root ganglion as well as the corticospinal, spino-cerebellar and brainstem-cerebellar systems (Tyrer, 1975; Barbeau, 1976; Oppenheimer, 1979). Obligatory features include dysarthria, ataxia, decreased position and vibration sense, muscle weakness and areflexia in the legs and an autosomal recessive mode of inheritance.

The peripheral sensory pathways are also affected, particularly the somatosensory system. Pathologically there is a loss of large myelinated fibres with relative sparing of small unmyelinated fibres (Hughes et al., 1968; Dyck \& Lambert, 1968; Dyck, 1975). Consistent with this finding, electrophysiological studies of peripheral nerves have shown abnormally small or absent sensory action potentials in the absence of clinical signs of peripheral neuropathy (Oh \& Halsey, 1973; Peyronnard et al., 1976; Bouchard et al., 1979).

Recently, Satya-Murti et al. (1980) described four Friedreich's ataxia patients with normal functional hearing, in whom no auditory brainstem responses (ABRs) could be recorded. Jabbari et al. (1981), however, reported on two affected siblings (aged 6 and 10 years), the younger of whom had normal ABRs while the older had more poorly defined responses. In an attempt to resolve this discrepancy as to the involvement of the auditory brainstem pathway in patients with Friedreich's ataxia, we tested ABRs in 16 patients who varied widely in age, degree of clinical involvement and the duration of their disorder. We also tested cortical auditory evoked responses (AERs) to investigate central as well as peripheral auditory system involvement.

\section{MATERIALS AND METHODS}

Sixteen patients (eight females) were tested: all met the diagnostic criteria of Friedreich's ataxia as established by the Quebec cooperative study (Geoffroy et al., 1976). Ages ranged from 6 to 37 (mean 20) years; 9 were 20 years old or younger at the time of testing. The mean onset of generalized symptoms was at 9 years. Twenty neurologically and audiologically normal young adults were controls for the ABRs; 12 served as normals for the AERs.

ABRs were recorded in all patients using a Grass Model 10 Evoked Response System, with high and low pass filter settings of 100 and $3 \mathrm{~K} \mathrm{~Hz}$, respectively, and a gain of $200 \mathrm{~K}$. The ABRs were recorded between the vertex and ipsilateral ear using Grass gold cup electrodes, attached with electrode paste and gauze. Electrode impedance was below $5 \mathrm{Kohms}$ in all subjects and below $2 \mathrm{Kohms}$ in most. Two averages of 1024 trials each were obtained at each intensity level tested.

Rarefaction $100 \mu \mathrm{sec}$ unfiltered clicks were presented monaurally via Telex 1470 headphones; a continuous white noise mask was presented contralaterally to avoid cross-stimulation. Clicks were presented first at $11 / \mathrm{sec}$ at $70 \mathrm{dBHL}$ ( $70 \mathrm{~dB}$ above the average hearing threshold of 10 normal hearing adults) in this laboratory. When clear replicable responses were obtained, clicks were then presented at a rate of 
$51 / \mathrm{sec}$ and the intensity was reduced until no response was elicited (i.e., threshold was reached). Where a clear response was not obtained at $70 \mathrm{dBHL}$, the click intensity was increased to 80 $\mathrm{dBHL}$, and if there was still no response, it was increased to $90 \mathrm{dBHL}$. No intensity level greater than 90 $\mathrm{dBHL}$ was used.

The AERs were recorded in 12 patients using the same equipment and montage as employed for the ABRs. The high and low pass filter settings were 1 and $100 \mathrm{~Hz}$, respectively, a gain of $20 \mathrm{~K}$ and a sweep time of $500 \mathrm{msec}$ were used. Monaural clicks were presented at a rate of $1 / \mathrm{sec}$ at 80 $\mathrm{dBHL}$, and two averages of 64 trials each were recorded for each ear. The patients were asked to count the clicks within each trial; this counting task ensured that the patients attended to the clocks and did not fall asleep. The patient lay on a bed during the testing and was asked to relax and to refrain from moving. Patient cooperation was excellent. The ABRs and AERs were recorded during the same session in all but one patient. Immediately preceding or following the evoked response studies, the patients underwent standard audiometric testing.

\section{RESULTS}

Two of the 16 patients had moderate bilateral hearing loss as determined by audiological testing; the remaining 14 had hearing within normal limits.

Table 1 shows the results of the ABRs, with the patients listed chronologically according to the duration of their illness. It appears that as the disease progresses, the waveforms of the $A B R$ tend to drop out, with the later waves disappearing first. Figure 1 shows this progression as seen across four patients. The first ABR, obtained from a child recently diagnosed as having Friedreich's ataxia, is within normal limits. The next four, from patients who have had the disorder for longer periods, show that later components of the ABR disappear first. In Figure $1 b$ wave $V$ has disappeared, only waves I and II are visible in $1 \mathrm{c}$ and only wave I in 1d. Figure le is typical of most of the patients responses at $70 \mathrm{dBHL}$, no recognizable waves being seen. All four of these patients had normal hearing.
TABLE I

\section{ABR LATENCIES FROM LEFT AND RIGHT EAR IN FRIEDREICH'S ATAXIA PATIENTS}

\begin{tabular}{|c|c|c|c|c|c|c|c|c|c|c|}
\hline Case & Age/Duration & 1 & 11 & III & IV & $\mathbf{v}$ & I-III & I.V & III-V & Threshold \\
\hline 1 & $6 / .5$ & $\begin{array}{l}+1.5 \\
+1.5\end{array}$ & $\begin{array}{l}2.5 \\
2.6\end{array}$ & $\begin{array}{l}3.6 \\
3.6\end{array}$ & $\begin{array}{l}4.3 \\
4.9\end{array}$ & $\begin{array}{l}5.4 \\
5.8\end{array}$ & $\begin{array}{l}2.1 \\
2.1\end{array}$ & $\begin{array}{l}3.9 \\
4.3\end{array}$ & $\begin{array}{l}1.8 \\
2.2\end{array}$ & $\begin{array}{l}<10 \\
<10\end{array}$ \\
\hline 2 & $14 / 3$ & $\begin{array}{l}\# 1.3 \\
1.4\end{array}$ & $\begin{array}{l}2.6 \\
2.7\end{array}$ & $\begin{array}{l}3.5 \\
3.6\end{array}$ & $\begin{array}{l}4.7 \\
4.8\end{array}$ & $\overline{5.5}$ & $\begin{array}{l}2.2 \\
2.2\end{array}$ & $\overline{4.1}$ & $\overline{1.9}$ & $\begin{array}{l}<10 \\
<10\end{array}$ \\
\hline 3 & $14 / 3$ & $\begin{array}{l}\# 1.6 \\
1.6\end{array}$ & $\begin{array}{l}2.5 \\
2.6\end{array}$ & $\begin{array}{l}3.5 \\
3.5\end{array}$ & $\begin{array}{l}4.8 \\
5.0\end{array}$ & - & $\begin{array}{l}1.9 \\
1.9\end{array}$ & - & - & $\begin{array}{l}<10 \\
<10\end{array}$ \\
\hline 4 & $23 / 6$ & $\begin{array}{l}+1.6 \\
\# 1.4\end{array}$ & $\begin{array}{l}2.9 \\
3.1\end{array}$ & $\begin{array}{l}4.4 \\
4.7\end{array}$ & $\begin{array}{l}5.7 \\
5.9\end{array}$ & $\begin{array}{l}6.4 \\
6.6\end{array}$ & $\begin{array}{l}2.8 \\
3.3\end{array}$ & $\begin{array}{l}4.8 \\
5.2\end{array}$ & $\begin{array}{l}2.0 \\
1.9\end{array}$ & $\begin{array}{l}<10 \\
<10\end{array}$ \\
\hline 5 & $17 / 7$ & $\begin{array}{l}\# 1.3 \\
\# 1.4\end{array}$ & $\begin{array}{l}2.7 \\
2.9\end{array}$ & $\begin{array}{l}3.9 \\
3.8\end{array}$ & $\begin{array}{l}5.0 \\
5.2\end{array}$ & - & $\begin{array}{l}2.6 \\
2.4\end{array}$ & 二 & - & $\begin{array}{l}<10 \\
<10\end{array}$ \\
\hline 6 & $17 / 7$ & $\begin{array}{l}\# 1.4 \\
\# 1.3\end{array}$ & $\begin{array}{l}2.7 \\
2.7\end{array}$ & $\overline{-}$ & $\overline{-}$ & - & - & - & - & $\begin{array}{l}<30 \\
<30\end{array}$ \\
\hline 7 & $28 / 10$ & $\begin{array}{l}\# 1.8 \\
\# 1.4\end{array}$ & $\begin{array}{l}2.8 \\
2.4\end{array}$ & $\overline{3.6}$ & $\overline{4.7}$ & $\overline{5.9}$ & $\overline{2.2}$ & $\overline{4.5}$ & $\overline{2.3}$ & $\begin{array}{l}<20 \\
<20\end{array}$ \\
\hline 8 & $16 / 10$ & $\begin{array}{r}* 1.5 \\
+1.7\end{array}$ & - & - & - & - & $\overline{-}$ & - & - & $\begin{array}{l}<10 \\
<10\end{array}$ \\
\hline 9 & $20 / 10$ & $\begin{array}{l}\# 1.3 \\
\# 1.4\end{array}$ & $\overline{-}$ & $\overline{-}$ & $\overline{-}$ & $\overline{-}$ & $\overline{-}$ & - & 二 & $\begin{array}{l}<10 \\
<10\end{array}$ \\
\hline 10 & $20 / 11$ & $\begin{array}{l}\# 1.4 \\
\# 1.5\end{array}$ & - & - & $\overline{-}$ & - & - & - & - & $\begin{array}{l}<40 \\
<50\end{array}$ \\
\hline 11 & $24 / 12$ & $\begin{array}{l}\# 1.4 \\
\# 1.3\end{array}$ & $\begin{array}{l}2.7 \\
2.5\end{array}$ & - & - & - & $\overline{-}$ & - & - & $\begin{array}{l}<10 \\
<10\end{array}$ \\
\hline 12 & $16 / 12$ & $\frac{\#-}{\# 1.7}$ & - & - & - & - & - & 二 & - & $\begin{array}{l}<10 \\
<10\end{array}$ \\
\hline 13 & $25 / 13$ & $\begin{array}{l}\# 1.5 \\
{ }^{*} 1.6\end{array}$ & - & - & 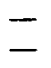 & - & - & - & - & $\begin{array}{l}<40 \\
<40\end{array}$ \\
\hline 14 & $23 / 18$ & $\begin{array}{l}\# 1.4 \\
\# 1.4\end{array}$ & $\begin{array}{l}2.7 \\
-\end{array}$ & $\overline{3.5}$ & $\overline{5.1}$ & 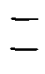 & $\overline{2.1}$ & $=$ & - & $\begin{array}{l}<10 \\
<10\end{array}$ \\
\hline 15 & $26 / 19$ & $\begin{array}{l}\#- \\
\# 1.6\end{array}$ & - & - & - & - & - & $\overline{-}$ & - & $\begin{array}{l}<10 \\
<30\end{array}$ \\
\hline 16 & $37 / 20$ & $\begin{array}{l}\# 1.5 \\
\# 1.7\end{array}$ & $\overline{3.1}$ & $\begin{array}{l}4.1 \\
4.1\end{array}$ & $\begin{array}{l}5.2 \\
5.4\end{array}$ & $\begin{array}{l}6.6 \\
6.7\end{array}$ & $\begin{array}{l}2.6 \\
2.4\end{array}$ & $\begin{array}{l}5.1 \\
5.0\end{array}$ & $\begin{array}{l}2.5 \\
2.6\end{array}$ & $\begin{array}{l}<10 \\
<10\end{array}$ \\
\hline
\end{tabular}

(a)

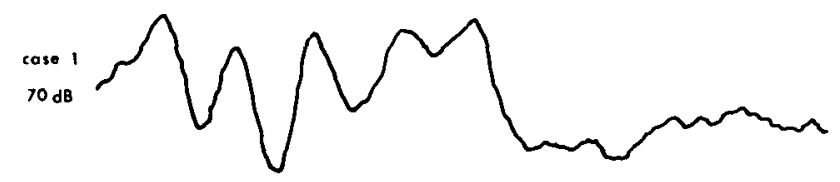

(b)

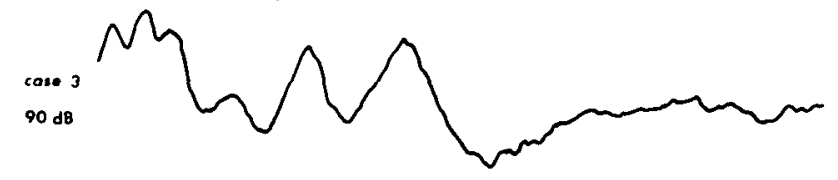

(c)

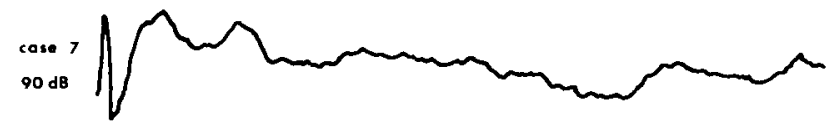

(d)

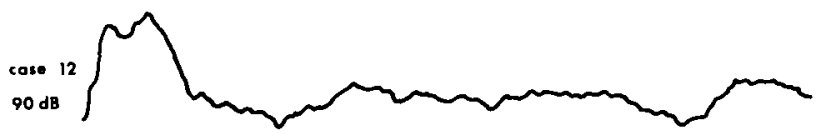

(e)

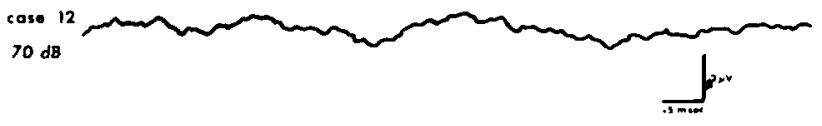

Figure 1 - ABRs recorded from four Friedreich's ataxia patient showing the loss of the waveform, the later waves disappearing first. The first ABR (case 1) was recorded from a child very recently diagnosed as having Friedreich's ataxia, the second had had the disorder for 3 years, the third for 10 years and the fourth for 12 years. 
With the deterioration of the ABR, the intensity required to elicit any waves increased. Only in the least affected patients could ABRs be obtained with $70 \mathrm{dBHL}$ clicks. For most, 80 or $90 \mathrm{dBHL}$ clicks were required to yield any responses whatsoever. In $88 \%$ of the patients one or more of the component waves of the ABR was missing, and in $50 \%$ only the first wave of two was visible at any intensity level.

Exceptions to the pattern of worsening ABRs with greater duration of the disorder, occurred in cases 4 and 16, both of whom have an unusually, more slowly progressive form of Friedreich's ataxia. In both the interwave latencies and the ABR were greatly increased, compared to normal controls, which implies slowed conduction through the brainstem. In case 16 and case 7 the waves were also very poorly defined.

Long latency AERs were tested in 12 of the 16 patients. Table 2 lists the mean latencies of the three major components from the patients and normal controls. AERs were recorded in all but two of the 12, although four had poor replicability; this is despite extremely abnormal responses in the more caudal segments of the auditory system in most of these patients. Both patients from whom AERs could not be elicited complained of hearing difficulty, yet one (case 11) had normal hearing thresholds on audiometric testing and the other (case 13) had mild to moderate hearing loss.

A repeated measures analysis of variance was performed on both the latencies of the AER waves and on the interwave latencies. The latency of the $\mathrm{N} 1$ and $\mathrm{P} 2$ waves were significantly longer in Friedreich's ataxia patients than in the normal controls [N1: $\mathrm{F}(1,19)=9.60, \mathrm{p}<.001 ; \mathrm{P} 2: \mathrm{F}(1,19)$ $=4.40, \mathrm{p}<.05]$. There was no significant difference in the latency of the P1 wave for the two groups. Significantly larger interwave latencies between $\mathrm{P} 1$ and $\mathrm{N} 1$, and $\mathrm{P1}$ and $\mathrm{P} 2$, were found with the Friedreich's ataxia patients compared to the normals $[\mathrm{F}(1,19)=$ $21.45, \mathrm{p}<.001 ; \mathrm{F}(1,19)=7.07, \mathrm{p}<$ .025 , respectively]. Despite these differences in latency between the two groups, only three of the Friedreich's ataxia patients had $\mathrm{N} 1$ or P2 latencies
TABLE II

AER MEAN LATENCIES FOR FRIEDREICH'S ATAXIA PATIENTS AND NORMAL CONTROLS Friedreich's ataxia ataxia

P1

N1 $41.7 \pm 14.3$ $90.9 \pm 21.9$

P2 $157.5 \pm 28.5$ Normal controls $\mathrm{p}<$ $43.8 \pm 10.5$ ns $71.9 \pm 6.8 \quad .001$

$139.2 \pm 14.2 \quad .05$

$\begin{array}{llll}\text { Pl-N1 } & 48.9 \pm 14.4 & 28.0 \pm 9.3 & .001\end{array}$

N1-P2 $65.0 \pm 13.6 \quad 67.3 \pm 15.3 \quad$ ns

$\begin{array}{llll}\text { P1-P2 } & 113.6 \pm 17.5 & 94.9 \pm 18.8 & .025\end{array}$

beyond the normal limits ( 2.5 s.d. above the mean).

\section{DISCUSSION}

The nature and incidence of auditory system involvement in Friedreich's ataxia has not been as well documented as that of the visual and somatosensory systems (Livingstone et al., 1981; Bouchard et al., 1979). Deafness has been reported in some cases (e.g. Sylvester, 1958; Bogaert, 1974) but it is not a common feature of this disorder. Only one of the patients referred to us for this study suffered profound hearing loss and was not included in this study. Nevertheless, our findings in this study suggest marked subclinical damage to both peripheral and central aspects of the auditory system in Friedreich's ataxia.

\section{ABRS}

The ABR is a widely accepted clinical measure of the integrity of the auditory pathway through the brainstem (Starr \& Achor, 1975; Stockard et al., 1977), as well as a measure of auditory threshold (Picton \& Smith, 1978; Despland \& Galambos, 1980). The ABR is a five-peaked waveform, each wave reflecting depolarization of the following sequential components of the auditory pathway: (I) VIIIth nerve, (II) cochlear nucleus, (III) superior olivary complex, (IV) lateral lemniscus and (V) inferior colliculus (Picton et al., 1974; Stockard \& Rossiter, 1977; Starr \& Hamilton, 1976). The latency of the waves varies with auditory threshold while the interwave latencies and morphology vary with abnormalities in the brainstem.

Satya-Murti et al. (1980) first reported the absence of ABRs in four Friedreich's ataxia patients, all of whom had had the disorder for 14 or more years. They suggested that their findings were the result of spiral ganglion degeneration, similar to that found with other sensory ganglia: degeneration of the large myelinated fibres, sparing the small unmyelinated ones.

Spoendlin (1974) reported two autopsied cases of Friedreich's ataxia and found that most of the outer spiral fibres were intact, whereas the inner fibres had disappeared. The afferent nerves to the inner hair cells are the large myelinated nerves and constitute approximately $95 \%$ of the auditory pathway; the small fibres supply the outer hair cells. Satya-Murti et al., suggested that functional hearing could be maintained with the small percentage of fibres from the outer hair cells, but that these were not sufficient to generate an ABR. Since they presented clicks at only 60-70 dBHL, their results are compatible with ours. In all patients who had had Friedreich's ataxia for more than seven years (with the exception of case 16) no responses could be obtained at $70 \mathrm{dBHL}$. Only at 80 or 90 $\mathrm{dBHL}$ did some waveforms emerge.

The observations of Jabbari et al., (1981) are also substantiated by our data; their six-year-old patient had normal ABRs whereas the ten-year-old had poor wave IV-V development. Our data extend their observation of the deterioration of the ABR with the duration of Friedreich's ataxia, having studied a wider age range of patients. The change in the ABR appears to be a gradual process and unlike the somatosensory or visual evoked responses (VER), abnormal ABRs do not seem to precede diagnosis. Repeated testing of the younger patients in this series may reveal that deterioration in the ABRs reflects more closely the rate of progression, rather than the existence of Friedreich's ataxia, as suggested by cases 4 to 16 .

The early loss of the late components in the ABRs may be explained by the pathological changes of cell loss and gliosis in the brainstem auditory pathways including inferior colliculus, superior olivary complex and cochlear nucleii described in autopsied cases of Friedreich's ataxia (Oppenheimer, 
1979). Although enough unmyelinated fibres are present to generate early components, they do not appear sufficient to induce the late components except in the very earliest stages of the disorder. Satya-Murti et al. (1979) suggested that temporal dispersion in more caudal areas of the auditory pathway could account for poor wave IV-V development, concordant with their model of spiral ganglion degeneration in Friedreich's ataxia (Satya-Murti et al. (1980). However, even progressive spiral ganglion degeneration could not account fully for our data. The gradual loss of the waves with time might reflect progressive neuronal loss in the brainstem.

Our results are an important anomaly in one of the current applications of ABRs. The ABR has been shown to be reliable in accurately determining auditory thresholds (e.g., Picton \& Smith, 1977). In the patients who had Friedreich's ataxia for seven or more years, their auditory thresholds as determined by the ABRs were all 70 $\mathrm{dBHL}$ or greater. Abnormalities of the auditory brainstem pathway prevented the usually accurate assessment of hearing threshold. It would be of interest to know if this effect is found with other degenerative disorders that occur in children for whom the ABR may be used as an auditory screening.

\section{AERS}

The unmyelinated fibres that must be spared in the degeneration, while not being sufficient to generate a normal ABR, appear to be sufficient for normal functional hearing which is reflected in the AERs. It is indeed an unusual circumstance to have essentially normal cortical responses when more peripheral aspects are clearly abnormal.

The AER results, which include increased latencies, increased interwave latencies and absent responses, suggest cortical involvement in audiologically asymptomatic Friedreich's ataxia patients. We do not believe that such abnormalities have been previously reported. Although the AERs were of increased latency in the Friedreich's ataxia patients as a group, only three had abnormally long latencies. The AERs do not seem to reflect the progression of the disorder as did the ABRs, although abnormalities when present were found only in those patients who had had the disorder for 10 or more years. The patients with abnormal AERs tended to have greater clinical involvement.

The pathological process in Friedreich's ataxia has been described as a "dying back" phenomenon with spinal cord -degeneration secondary to degeneration in the dorsal root ganglion. Mild neuronal changes have been found in the cerebral cortex of some autopsied Friedreich's ataxia cases (Oppenheimer, 1979) and VER studies have suggested cortical visual pathway dysfunction (e.g., Livingstone et al., 1981). The prolonged latencies in the AERs in our patients also suggest involvement of the cortical auditory system. This finding, in addition to suggesting more widespread involvement of the brain in Friedreich's ataxia patients, could reflect a central "dying back" pattern with the major pathological changes occurring in the spiral ganglion, less severe degeneration in the brainstem and minimal involvement of more rostral neurons as a consequence of the same pathogenetic mechanism.

There appear to be parallels between our data and research on the visual system in Friedreich's ataxia. Livingstone et al. (1981) also found no clear relationship between VER abnormalities and the disease progression, although Carroll et al. (1980) did report such a relationship. Kirkham and Coupland (1981) very recently reported electroretinographic abnormalities in Friedreich's ataxia patients, as well as abnormal VERs, concordant with our data in showing both peripheral and central abnormalities in an asymptomatic sensory system. The findings of increased interwave latencies could suggest abnormal temporal dispersion of the response as has been noted in some studies of the visual system (Bird \& Crill, 1981; Livingstone et al., 1981; Kirkham \& Coupland, 1981). Based on such VER data, it has been suggested that there is diffuse and possibly progressive loss or shrinkage of nerve fibres with associated paranodal demyelination and slowing of con- duction (Carroll et al., 1980; Kirkham $\&$ Coupland, 1981).

The results of this study confirm earlier reports of abnormal ABRs in audiologically asymptomatic Friedreich's ataxia patients. The study is significant in having tested a series of patients varying widely symptomatically and in showing that the changes in the ABR occur as a function of the severity and duration of the disease. This may prove to be a reliable means of monitoring the progression of the disease; this could be of particular value in assessment of future therapeutic interventions. Longitudinal studies are now in progress in our department to further clarify the temporal relationship of the changes in the ABR with the degenerative process in Friedreich's ataxia.

The study is also significant in demonstrating cortical involvement in the auditory system in Friedreich's ataxia. Although the study found abnormalities in the AER's, the relationship with the disease state was not as clear as that found with the ABR's, but quite similar to results found with VER's (e.g., Kirkham \& Coupland, 1981). The longitudinal studies may also improve our understanding of the cortical changes that accompany this disorder.

\section{ACKNOWLEDGEMENTS}

Dr. M.J. Taylor was a post-doctoral fellow of the Research Institute of the Montreal Children's Hospital while this research was conducted.

We wish to thank the Audiology Department and Mme F. Guérin particularly for testing all of the Friedreich's ataxia patients. We are grateful for the helpful discussions with Drs. T.H. Kirkham, S.G. Coupland and A. Ouapick.

\section{REFERENCES}

BARBEAU, A. (1976) Friedreich's ataxia 1976 - An overview. Can. J. Neurol. Sci. 3: 389. 398.

BIRD, L.D. \& CRILL, W.E. (1981) Patternreversal visual evoked potentials in the hereditary ataxias and spinal degenerations. Ann. Neurol., 9: 243-250.

BOGART, L.V. \& MARTIN, L. (1974) Optic and cochleovestibular degenerations in the hereditary ataxias. I. Clinico-pathological \& genetic aspects. Brain, 97: 15-40. 
BOUCHARD, J.P., BARBEAU, A., BOUCHARD, R. \& BOUCHARD, R.W. (1979) Electromyography and nerve conduction studies in Friedreich's ataxia and autosomal recessive spastic ataxia of Charlevoix-Saguenay (ARSACS). Can. J. Neurol. Sci., 6: 185-189. Sci.

CARROLL, W.M., KRISS, A., BARARTSER, M., BARRETT, G. \& HALLIDAY, A.M. (1980) The incidence and nature of visual pathway involvement in Friedreich's ataxia. Brain, 103: 413-434.

DESPLAND, P.A. \& GALAMBOS, R. (1980) The auditory brainstem response (ABR) is a useful diagnostic toolk in the intensive care nursery. Ped. Res. 14: 154-158.

DYCK, P.J. (1975) Inherited neuronal degeneration and atrophy of peripheral, motor, sensory and autonomic neurons. In Peripheral Neuropathy, P.J. Dyck, P.K. Thomas \& E.H. Lambert (Eds.), W.B. Saunders Co., New York.

DYCK, P.J. \& LAMBERT, E.H. (1968) Lower motor and primary sensory neuron diseases with peroneal muscular atrophy. II. Neurologic, genetic and electrophysiologic findings with various neuronal degenerations. Arch. Neurol. 18: 619-625.

GEOFFROY, G., BARBEAU, A., BRETON, G., LEMIEUX, B., AUBE, M., LEGER, C. $\&$ BOUCHARD, J.P. (1976) Clinical description and roentgenologic evaluation of patients with Friedreich's ataxia. Can. J. Neurol. Sci., 3: 279-286.

HUGHES, J.T., BROWNELL, B. \& HEWER, R.L. (1968) The peripheral pathway in Friedreich's ataxia. Brain, 91: 803-818.
JABBARI, B., SCHWARTZ, D., CHIKARMANE, A. \& FADDEN, D. (1981) Somatosensory and brainstem auditory evoked response abnormalities in a family with Friedreich's ataxia. Paper presented at the American EEG. Society Meeting, Chicago, June 1981.

KIRKHAM, J.H. \& COUPLAND, S.G. (1981) An electroretinal and visual evoked potential study in Friedreich's ataxia. Can. J. Neurol. Sci. 8: 289-294.

LIVINGSTONE, J.R., MASTAGLIA, F.L., EDIS, R. \& HOWE, J.W. (1981) Visual involvement in Friedreich's ataxia and hereditary spastic ataxia. Arch. Neurol., 38: 75-79.

NODER, R.H., HALM, J. \& LEVINE, H.L. (1980) Brainstem auditory evoked esponses in determining site of lesion of brain stem gliomas in children. Laryngoscope, 90: 258265.

OH, S.J. \& HALSEY, J.H. (1973) Abnormality in nerve potentials in Friedreich's ataxia. Neuro., 23: 52-54.

OPPENHEIMER, D.R. (1979) Brain lesions in Friedreich's ataxia. Can. J. Neurol. Sci., 6: 173-176.

PEYRONNARD, J.M., LAPOINTE, L., BOUCHARD, J.P., LAMONTAGNE, A., LEMIEUX, B. \& BARBEAU, A. (1976) Nerve conduction studies and electromyography in Friedreich's ataxia. Can. J. Neurol. Sci., 3: 313-317.

PICTON, T.W., HILLYARRD, S.A. and KRAUSZ, H.I. (1974) Human auditory evoked potentials: I. Evaluation of components. Electro. clin. Neurophysio., 36: 179190.
PICTON, T.W. \& SMITH, A.D. (1978) The practice of evoked potential audiometry. Otolaryng. Clin. N. Amer., 11:263-282.

SATYA-MURTI, S., CACACE, A.T. \& HANSON, P.A. (1979) Abnormal auditory evoked potentials in hereditary motorsensory neuropathy. Ann. Neurol., 5: 445448.

SATYA-MURTI, S., CACACE, A.T. \& HANSON, P.A. (1980) Auditory dysfunction in Friedreich's ataxia: Result of spiral ganglion degeneration. Neurology 30: 10471053.

SPOENDLIN, H. (1974) Optic and cochleovestibular degenerations in hereditary ataxias. Brain, 97: 41-48.

STARR, A. \& ACHOR, L.J. (1975) Auditory brainstem responses in neurological disease. Arch. Neurol., 36: 761-772.

STARR, A. \& HAMILTON, A.E. (1976) Correlation between confirmed sites of neurological lesions and abnormalities of far-field auditory brainstem responses. Electro. clin. Neurophysio., 41 : 595-608.

STOCKARD, J.J. \& ROSSITER, V.S. (1977) Clinical and pathologic correlates of brainstem auditory response abnormalities. Neurol., 27: 316-325.

STOCKARD, J.J., STOCKARD, J.E. \& SHARBROUGH, F.W. (1977) Detection and localization of occult lesions with brainstem auditory response. Mayo Clin. Proc., 52: 761-769.

SYLVESTER, P.E. (1958) Some unusual findings in a family with Friedreich's ataxia. Arch. Dis. Childhood, 53: 217-221. 